\title{
慢性関節リウマチの金療法中に発症したびまん性 間質性肺炎の一例
}

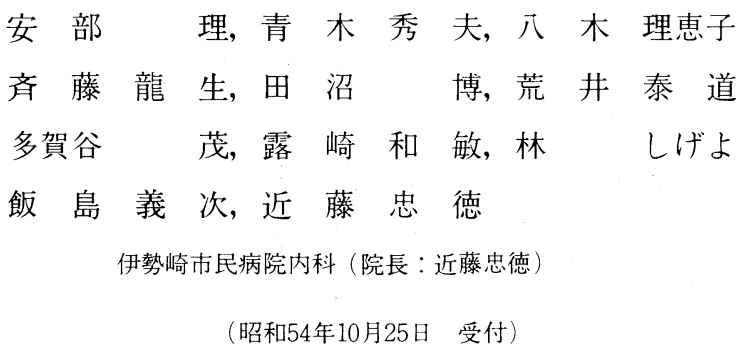

\section{は じめに}

金製剂として現在用いられているものには油性の gold thioglucose と水性の gold thiomalate がある. これらの金製剂は主として慢性関節りウマチや気管 支喘息に対し有効性が認女られ，わが国では広く用 いられている。その副作用としては，皮疹，口内炎， 脱毛, 腎機能障害, 骨髄障害, 胃腸障害, 眼障害等

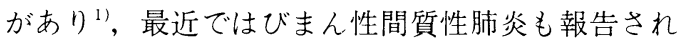
注目されている ${ }^{9 / 177}$. 今回われわれは慢性関節リウ マチ患者に対し, 水性 gold thiomalate の投与中に, 口内炎, 皮疹, 脱毛, びまん性間質性肺炎を併発し た症例を経験したので報告する。

$$
\text { 症例 }
$$

患者：44才，女性。

主訴：両側膝関節の腫脹と疼痛.

既往歴：特記すべきことなし。

家族歴： 特記すべきことなし。

現病歴： 昭和52年 6 月頃より両側膝関節の腫脹 と疼痛がみられ，9月上旬某病院を受診し，関節炎 といわれ治療していたが, 膝関節痛は持続し，10月 下旬には朝のこわばりもみられるようになり，微熱 も出るようになった。11月に某大学病院を受診し， 慢性関節リウマチと診断され治療を受けていたが, 昭和53年 1 月下旬より両側膝関節の腫脹および疼痛 が増強したため当院内科を紹介され， 3 月. 1 日入院 した。

入院時所見：体格栄養中等度, 体温 $36.7^{\circ} \mathrm{C}$, 脈 拍 84 回/分整, 血圧 $124 / 86 \mathrm{~mm} H$, 眼球結膜に黄疸はな く，眼瞼結膜は軽度貧血性，表在リンパ節は触知せ

\begin{tabular}{|c|c|c|c|c|c|}
\hline $\begin{array}{l}\text { 尿 } \\
\text { 䔬便 }\end{array}$ & $\begin{array}{l}\text { 蛋白 }( \pm) \\
\text { 潜血 }(-)\end{array}$ & 糖 $(-)$ & 沈渣 & 異常なし & \\
\hline 液 & 赤血球数 & $349 \times 10^{4}$ & & 白血球数 & 5400 \\
\hline & $\mathrm{Hb}$ & $10.4 \mathrm{~g} / \mathrm{d} \ell$ & & 桿状球 & $4 \%$ \\
\hline & $\mathrm{Ht}$ & $30 \%$ & & 分葉球 & $71 \%$ \\
\hline & 網状赤血球数 & $12 \%$ & & 好酸球 & $1 \%$ \\
\hline & 血 小板 & $33.9 \times 10^{4}$ & & $\begin{array}{l}\text { 単 球 } \\
\text { リンパ球 }\end{array}$ & $\begin{array}{r}3 \% \\
21 \%\end{array}$ \\
\hline
\end{tabular}

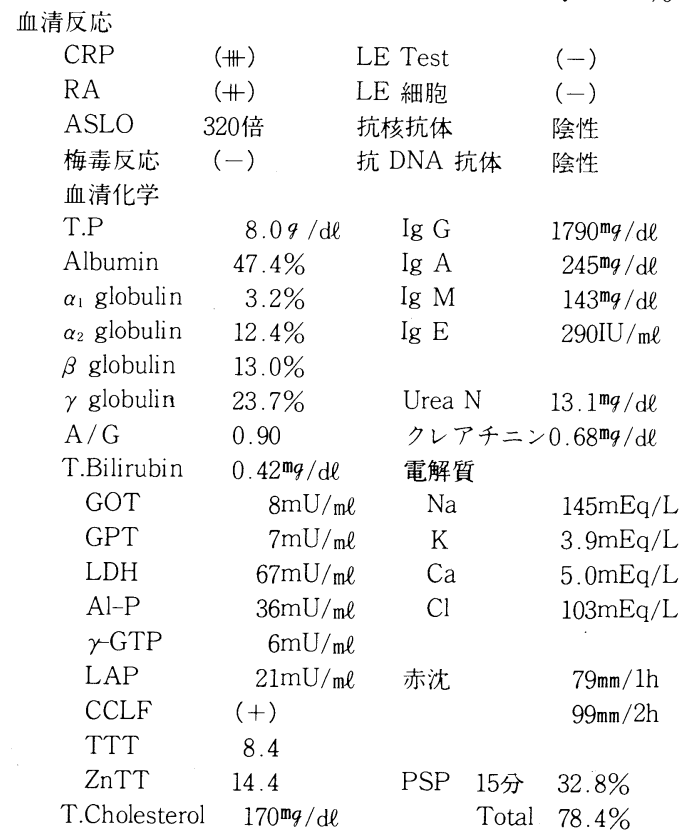

ず，胸部では心尖部で収縮期雑音が聴取された以外 は異常なく，腹部では肝脾は触知しなかった。左右 膝関節の腫脹，疼痛および熱感がみとめられたが, 他の関節には著変はみられなかった。 

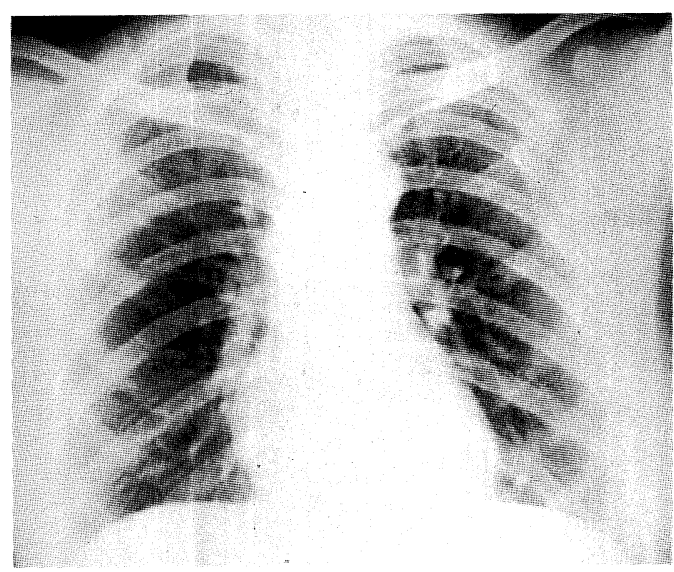

S53. 3. 2

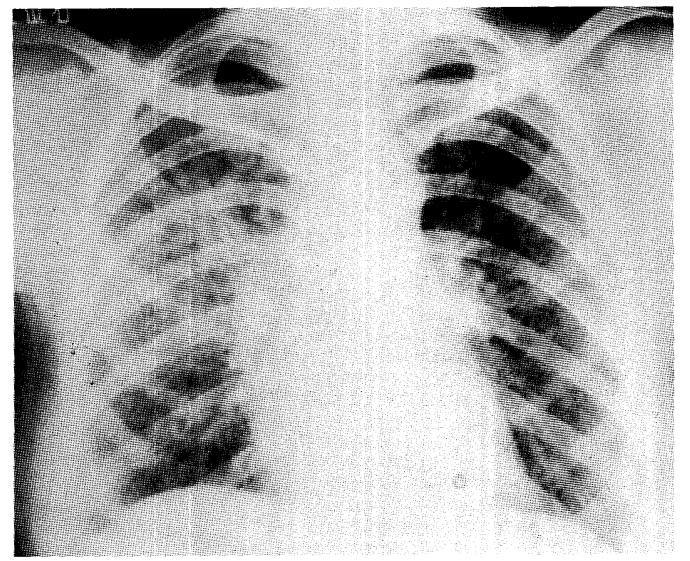

S53. 6.30
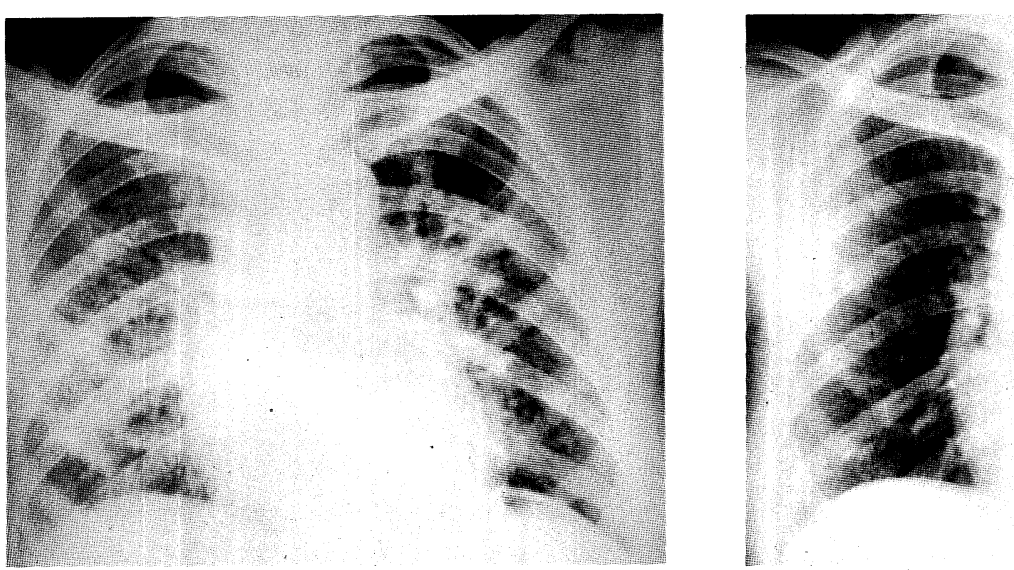

S53. 8.10

S53. 8.28

図 1
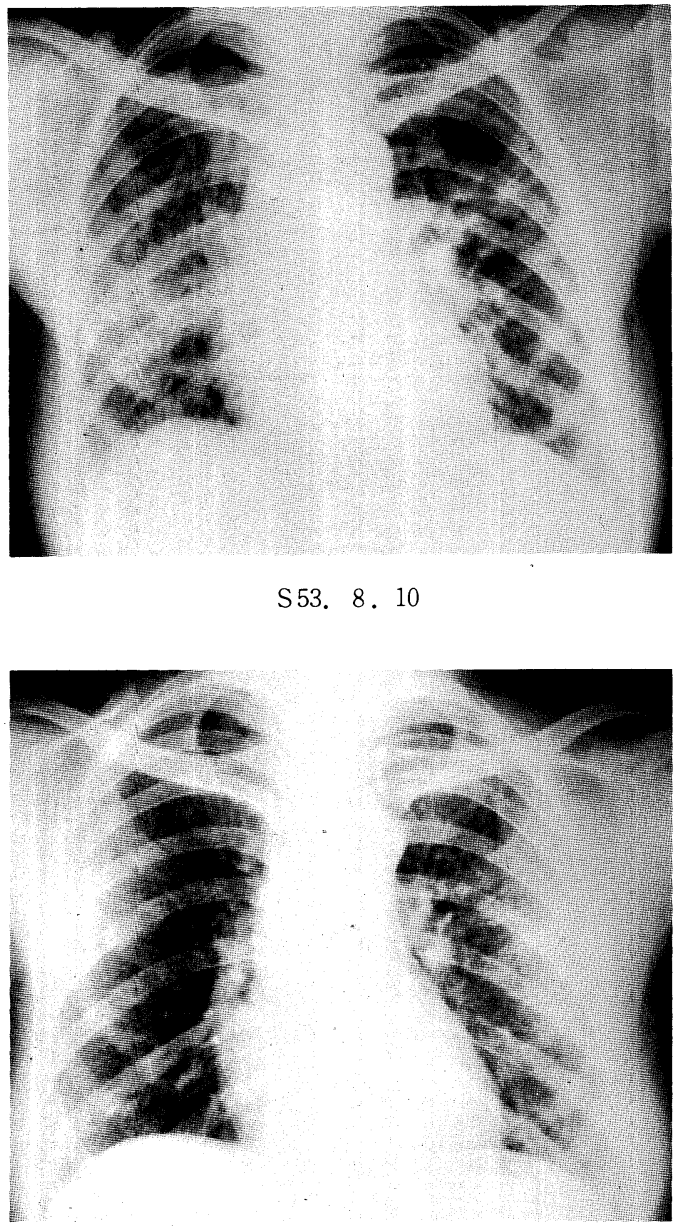

S53. 11. 28 
金療法中に発症したびまん性間質性肺炎

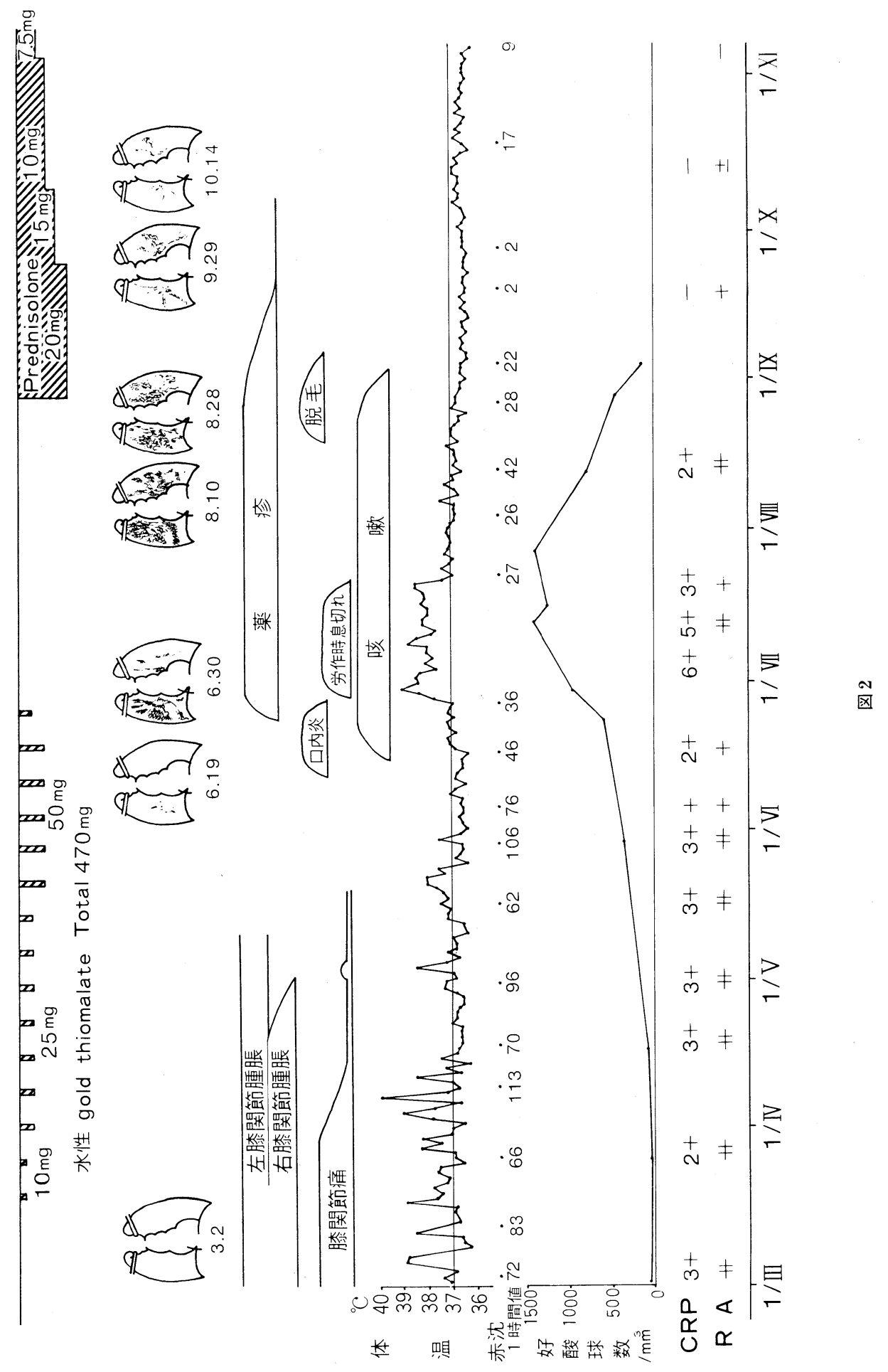


入院時検查所見 (表 1)：胸部 X-Pには異常な く(図 1 ), 表 1 に示したごとく軽度の貧血, 赤沈の 穴進, RAH, CRP $3+$ +おび $\gamma$-globulin の軽度増加 がみとめられた。

入院後経過（図 2)：3月20日より水性 gold thiomalate $10^{\mathrm{mg}}$ より投与開始し，図 2 に示すよう に漸增した。 4 月には左右膝関節の疼痛は減弱し, 左膝関節の腫脹のみがみられるだけとなった。6月 より赤沈值も改善してきたが，6月13日には口内炎 (金剤総投与量 $395 \mathrm{mg}), 16$ 日には乾性咳嗽が出現し， 19日の胸部X-Pでは右中肺野に小斑状および網状 影がみられ(図 1 )，24日には好酸球数の増加ととも に皮疹ができはじめた（金剤総投与量 $445 \mathrm{~m} g$ )。その ため水性 gold thiomalate の副作用と考之 6 月26日 総投与量 $470^{\mathrm{m} g}$ で投与を中止した。しかし呼吸器症状 および皮疹は軽快せず，30日には労作時の息切れが 出現し, その際の胸部 X-Pでは右上中肺野にスリガ ラス状の㓌影の中に, 小斑点状㓌影がみられ, 聴診 上では呼吸音は粗で呼気の延長が認められた。7 月 10日皮疹は痂皮の形成とともに落屑がみられるよう になり, 群大皮膚科にて gold exanthem と診断され た（図 3 ).8月10日胸部 X-Pでは左上肺野に索状 㓌影，左中肺野に小斑点状網状陰影がみられるよう になった（図１）。この時点で右鎖骨下で気管支音を 聴取しえたが, Velcro 音は聴取されなかった。 8 月 20日より頭髪と眉毛の脱毛がみられるようになっ た。

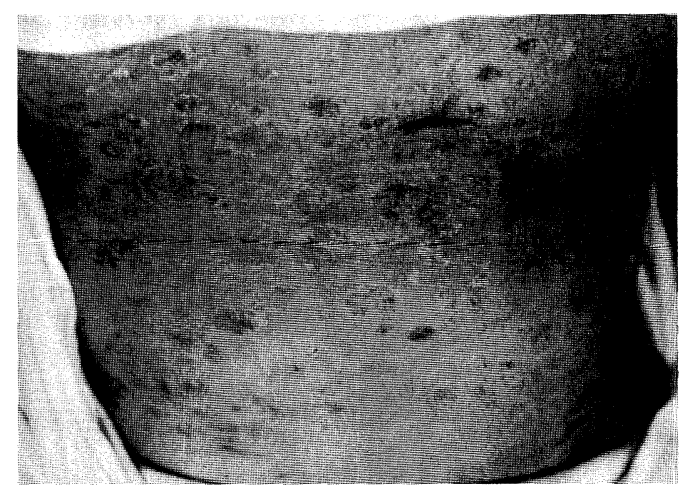

図 3

呼吸器症状および肺野の異常陰影は, 慢性関節り ウマチの症状が軽快した時期にみられ，また金製剤 による一連の副作用である口内炎, 皮疹, 脱毛の発 現に従って好酸球增多とともに発症してきたこと,
胸部 $\mathrm{X}-\mathrm{P}$ 上の異常院影が特に左右の上中肺野につ よくみられることから，慢性関節りウマチに合併す る間質性肺炎とは考えにくく，従って金製剤により 発症したびまん性間質性肺炎と診断し，8月30日よ り) Prednisolone $20^{\mathrm{m} g} / \mathrm{day}$ の投与を開始した。投与 開始後咳嗽, 薬疹は急速に軽快し, 脱毛も止まり, 約 1 力月で胸部 $\mathrm{X}-\mathrm{P}$ 上の異常㓌影も明らかな改善 がみとめられた。そして図1に示したごとく 11 月 28 日には胸部 X-Pにみられた異常陰影はほとんど消 失した。この時点での Prednisolone の総投与量は 1195mgであった。

\begin{tabular}{|c|c|c|c|c|}
\hline \multirow[t]{2}{*}{ 表 2} & \multicolumn{3}{|c|}{ 肺機能 検 查 } & \multirow[b]{2}{*}{$\mathrm{S}^{5} \mathrm{~g} / \mathrm{V}$} \\
\hline & \multicolumn{2}{|c|}{ S53 } & $28 / \mathbb{X}$ & \\
\hline $\mathrm{VC}$ & $1580 \mathrm{~m} \ell$ & $2392 \mathrm{~m} \ell$ & $2740 \mathrm{~m} \ell$ & $2710 \mathrm{~m} \ell$ \\
\hline$\% \mathrm{VC}$ & $56.4 \%$ & $85.4 \%$ & $95 \%$ & $101 \%$ \\
\hline FEV 1.0 & $1212 \mathrm{~m} \ell$ & $1648 \mathrm{~m} \ell$ & $2270 \mathrm{~m} \ell$ & $2450 \mathrm{~m} \ell$ \\
\hline FEV $1.0 \%$ & $76.7 \%$ & $68.9 \%$ & $86 \%$ & $86 \%$ \\
\hline 拡散 & & & $57 \%$ & $72 \%$ \\
\hline & $\begin{array}{l}\text { 血 } \\
\mathrm{S}\end{array}$ & ガス分 & & \\
\hline & & $18 /$ VII & & $22 / \mathrm{IX}$ \\
\hline $\mathrm{PO}_{2}$ & & $72 \mathrm{mmHg}$ & & $102 \mathrm{mmHg}$ \\
\hline $\mathrm{PCO}_{2}$ & & $34 \mathrm{mmHg}$ & & $33 \mathrm{mmHg}$ \\
\hline $\mathrm{pH}$ & & 7.405 & & 7.400 \\
\hline $\mathrm{HCO}_{3}^{-}$ & & $0.9 \mathrm{mEq} / \mathrm{L}$ & & $19.8 \mathrm{mEq} / \mathrm{L}$ \\
\hline $\mathrm{BE}$ & & $3.0 \mathrm{mEq} / \mathrm{L}$ & & $-3.7 \mathrm{mEq} / \mathrm{L}$ \\
\hline
\end{tabular}

表 2 に肺機能と血液ガスの結果を示した。 8 月30 日 Prednisolone 投与前の肺機能では拘束性障害が みられたが，9月28日には正常化した。拡散につい ては 9 月28日57\%であったが, 回復が遅く, 昭和54 年 5 月になってもまだ $72 \%$ であった。血液がスでは 7 月18日の酸素分圧は軽度低下していたが，9月22 日には正常化がみられた。以後は外来で経過観察中 であるが，呼吸器症状は全く訴えていない。

考

案

金製剤の作用機序は今日なおその詳細は明らかで ないが，世界中で主として慢性関節りウマチの治療 に有効性が認められ²，わが国では気管支喘息に対 しても二重盲検法により，その有効性が実証されて いる3). 現在用いられているものには油性の gold thioglucose と水性の gold thiomalate とがあり, ど ちらも腎臓より排泄される。血中濃度は注射後数日 で半減し，50日でほぼ0となるといわれている4).金 


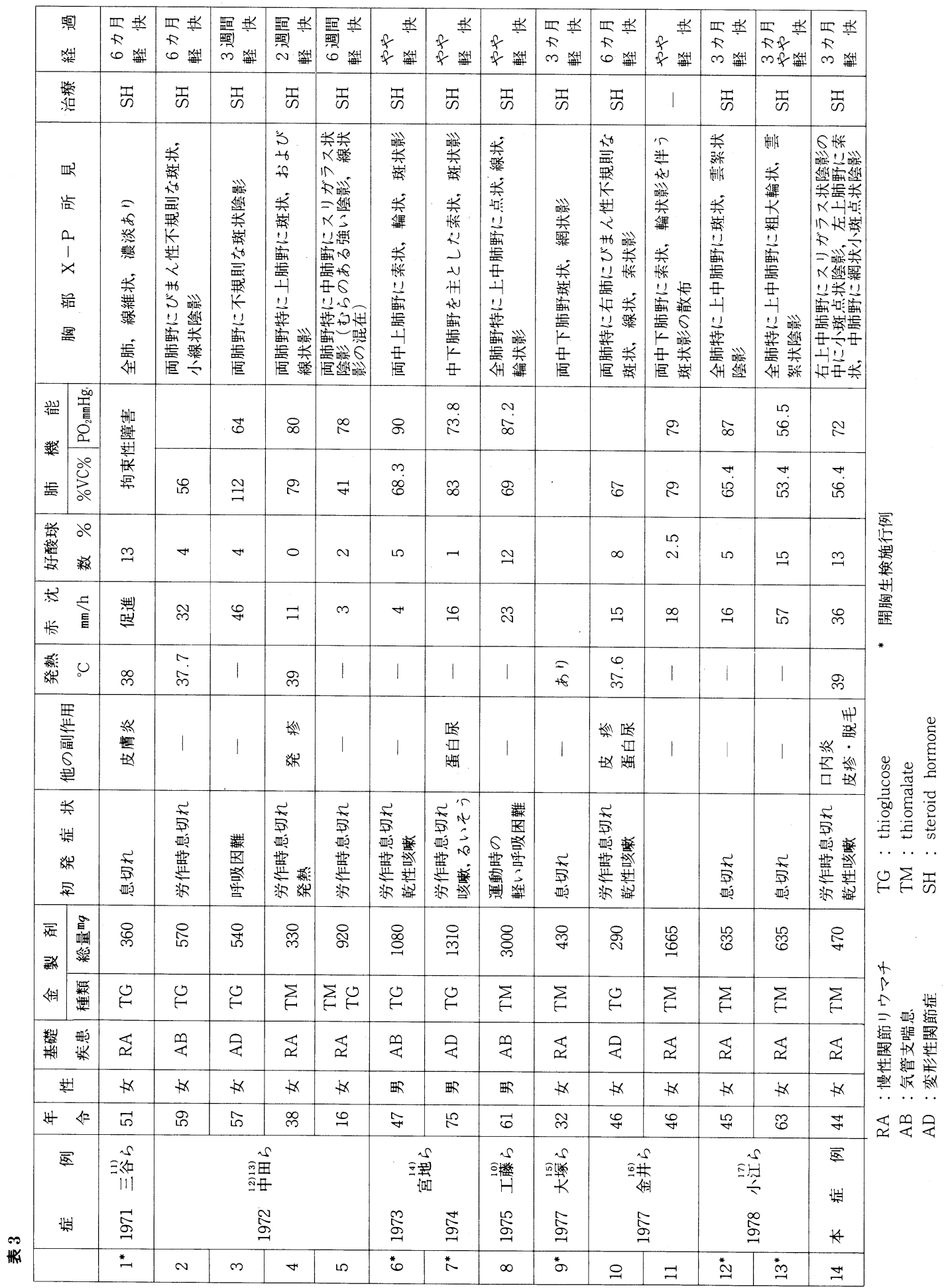


製剤による副作用の発現率は，報告者により異なる が, 平均して $30 \%$ 位といわれているらへて7)。その副作用 としては, 肝障害, 腎障害, 造血器障害 (白血球減 少, 血小板减少, 再生不良性貧血, 無顆粒細胞症), 皮膚症状 (発疹, 色素沈着, 剝脱性皮膚炎, 脱毛, 口内炎, 舌炎, 結節性紅斑), 眼障害 (結膜炎, 角膜 潰瘍，角膜金沈着症，網膜出血)，胃腸障害，間質性 肺炎等がある。副作用の中で最も多いのは発疹であ り, Hartfall と Garland ${ }^{8)}$ は副作用の69\%は皮䖉反応 であると報告している，皮膚以外の諸臟器に対する 副作用としては, 腎障害が次いで多くみられるが, そのほとんどは一過性の蛋白尿である。

金製剂による間質性肺炎は，わが国のみでなく外 国でも報告されているが99，工藤らの報告によると その発生頻度は比較的稀なものと考えられてい $3^{10)}$.

本症例は，慢性関節リウマチに対し水性 gold thiomalate の投与中に口内炎, 皮疹, 脱毛, びまん 性間質性肺炎といった一連の副作用の発現がみられ た症例である。この際金製剂による間質性肺炎と慢 性関節リウマチに伴う間質性肺炎との鑑別が問題と なるが，本症例は

1）慢性関節リウマチの症状が軽快した時期に発症 したこと。

2）金製剂による一連の副作用である口内炎, 皮疹, 脱毛およびこれら副作用の発現に伴って好酸球増 多とともに発症してきたこと。

3）胸部 X-P 上の異常陰影は, 上小よび中肺野にス リガラス状, 索状, 小斑状, 網状影がつよくみら れ下肺野には少なかったこと。

4）膠原病の肺病変に特徵とされる胸水や胸膜の病 変はみられなかったこと。

5）治療による胸部 X-P 上の異常陰影の消褪が速 やかで，その後の再発を認めなかったこと.

などから金䳤剤によって発症した間質性肺炎と考之 られた。

1971年からわが国で報告された13例にわれわれの 1 例を加えて14例についてまとめて表3に示した。 内訳は気管支喘息 3 例, 慢性関節リウマチ 8 例, 変 形性関節症 3 例である。性別では男 3 例, 女11例と比 較的女性に多くみられるようである。年令は16才か ら75才で平均は49.6才であったが，40才代が5例と 一番多く, 次いで50才代が 3 例であり，30才代と60 才代がそれぞれ2例ずつであった。したがって例数
は少ないが40～50才代が過半数以上を占めているの で，この年代に好発する傾向があるようである．使 用した金製剂は gold thioglucose 6 例, gold thiomalate 7 例, 両者併用 1 例であり, 水性のものと油 性のものとの間に差はないものと思われた。間質性 肺炎発症までの累積使用量は $290^{\mathrm{mg}} \mathrm{g} ら 300 \mathrm{omg}^{\mathrm{m}}$ と症 例によって大差がみられている。しかし使用量別に みると，300 600m $g$ 前後で発症したものが 9 例で最 も多く, 次に $1000^{\mathrm{m} g}$ 前後のものが 3 例で, $1665 \mathrm{~m} g$ お

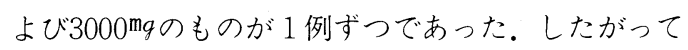
われわれの例もそうであったが, 300 600 $\mathrm{m}$ 前後で 発症するものが多い傾向であるように思われた。平 均累積使用量は $874 \mathrm{mg}$ であった。

初発症状としては労作時の息切れを訴えるものが ほとんどであり，次いで咳嗽が 4 例にみとめられて いる. 他の副作用としては皮疹が 4 例, 蛋白尿が 2 例, 口内炎と脱毛が 1 例にみられた。また好酸球増 多は14例中 5 例に, 赤沈の元進は 8 例, 発熱は 6 例 にみられた。少江ら ${ }^{17)}$ は赤沈の元進は少ないと報告 しているが，14例中 8例（57\%）でえ進しており決 して少ないとはいえない。

胸部 X-Pでは全肺野にびまん性に広がる浸潤な いしは斑状, 輪状, 線状, 雲絮状㓌影を示し, 濃淡 があり不均一なことが多いが, 本症例でもスリガラ 又状, 索状, 小斑状, 網状陰影を呈し, 右肺よりは じまり次第に左肺へと拡大していった。また病変に 左右差があり右肺につよくみられた。病変の分布は 下肺野よりも上中肺野につよいといわれているが, 本症例もそうであった。

肺機能検查では拘束性障害を呈するものが多い が,血液がスでは $\mathrm{PO}_{2}$ の著明な低下を示したものは 少なかった。拡散は本症例以外は施行していないが, 本症例では57\%と障害がつよくみと好, 治療に より血液がス, 拘束性障害の肺機能が正常化したあ とも回復が遅れ，治療開始 9 力月後でもなお $72 \%$ で あったここことは自覚症状の改善や胸部 $\mathrm{X}-\mathrm{P}$ 上の 改善のみでは間質性肺炎が完治したと判断するのは 問題であり, 間質性肺炎の経過観察上肺拡散能の測 定は当然施行されるべき検査であると考えられる.

開胸生検は14例中 6 例に行われているが(1114)15 ${ }^{17)}$, 組織学的には肺胞壁の肥厚と小円形細胞浸潤, 肺胞腔には脱落上皮, マクロファージ, 滲出液など を認め, 間質性肺炎の所見を呈し, 慢性関節リウマ チに認められるマッソン体や血管炎の所見は認めら 
れていない.

治療については14例中 1 例は金製剤の中止のみで 自然寛解しているが16)，他の13例については corticosteroid の投与が行われ，ほとんどの例が投与後 6 カ月以内で, 早いものは 2 週間で胸部 $\mathrm{X}-\mathrm{P}$ 上の所見 や自覚症状が軽快しており，ステロイド剤がきわめ て有効である.

金製剤によるびまん性間質性肺炎の発症機序は未 だ不明な点が多いが，1）皮䖉炎, 骨髄障害, 腎障害 を起こすことがある．2）Rrausnitz-Kustner 反応陽 性例がある ${ }^{18)}$. 3) リンハ球幼若化試験陽性例の存 在 ${ }^{7)}$.4）好酸球增多を示す例があること ${ }^{19)}$.5）肺に おける金濃度は特に高くない ${ }^{14)}$.などから金自体の 組織毒によって発症するとは考之難く, 何らかの免 疫機序の関与が推定されている. 金製剂の使用対象 は主に気管支喘息や慢性関節りウマチであり，これ らの疾患はともにアレルギ一や免疫の機序がその発 症や経過に密接な関連を有する疾患であり，金製剂 の作用機序の解明とともに副作用発現の機序の解明 も今後明らかにされるものと思われる。いずれにし ても金製剤の使用にあたっては，副作用としては間 質性肺炎等を惹きおこす可能性があることを常に念 頭においておくことが必要であると考えられる。

\section{結語}

慢性関節リウマチの44才の女性例に対し金療法を 行い, その経過中に口内炎, 皮疹, 脱毛等の副作用 とともに間質性肺炎をきたした症例を経験したので 報告するとともに, 従来の報告例13例を加え, 若干 の文献的考察を行った。

本論文の要旨は昭和54年 6 月第293回日本内科学会関東地 方会で発表した。

\section{文}

献

1）本間光夫, ほか：新内科学大系第 7 卷 $\mathrm{A}$, 中 山書店, 東京, 1976年, 322頁.

2) Gold therapy in rheumatoid arthritis. Final report of a multicentre controller trial, arranged by the Research Sub-committee of the Empire Rheumatism Council, Ann. Rheum. Dis., $20: 315,1961$.

3）村中正治，ほか：二重盲検法による金塩の気 管支喘息に対する治療効果の判定, 第72回日本
内科学会講演, 1975.

4）宮本昭正，ほか：気管支喘息の金療法に関す 了研究, 日内誌., 63:1190, 1974.

5) Rook, A., Wilkinson, D.S. \& Ebling, F.J.G. : Text book of Dermatology, 1st ed. pp. 386.

6) Almeyda, J. \& Baker, H. : Cutaneous reactions to anti-rheumatic drugs, Brit. J. Derm., $83: 707,1970$.

7) Walzer, R.A. et al. : Severe hypersensitivity reaction to gold, Arch. Derm., $106: 231,1972$.

8) Hartfall, J.S., Garland, H.G. \& Goldie, W. : Gold treatment of arthritis, Lancet, $2: 838$, 1937.

9) Richard, H.W., Kenneth, R.W \& Roger, F.W. : Diffuse pulmonary injury associated with gold treatment, New Engl. J. Med., 294 : 917, 1976.

10）工藤宏一郎，ほか：金製剂によると思われる 肺線維症の 1 症例と気管支喘息患者の金療法中 の胸部 X線像の検討, 日本胸部疾患学会誌, 15 :646, 1975.

11）三谷 登，中村桂吾：金製剤ゾルガナールの 投与によると思われる皮膚炎および間質性肺炎 を示した 1 症例, 広島医学, 24:729, 1971.

12）中田紘一郎，谷本晋一： 金療法の経過中に胸 部X線上びまん性除影を呈した 4 症例, 日本胸 部疾患学会誌, $11: 314,1973$.

13）谷本晋一，ほか：間質性肺炎の治療，呼吸と 循環, $23: 37,1975$.

14）宮地純樹，ほか：金製剂使用中に発症した間 質性肺炎に関する研究, 日本胸部疾患学会誌, $13: 653,1975$.

15）大塚盛男，ほか：慢性関節リウマチの金療法 中発症した間質性肺炎の 1 生検例, 日本胸部疾 患学会誌, $15: 226,1977$.

16）金井久容，ほか：金製剂使用中に発症した間 質性肺炎の 2 例, 信州医誌, $25: 296,1977$.

17）小汇俊行，ほか：金製剂使用中に発症した間 質性肺炎の 2 例, 日胸., $37: 736,1978$.

18) Molgensterm, A. et al. : Arzneimittelallergie nach Goldmedikation, Zschr. ges. inn. Med., $11: 848,1956$.

19) Jessop, J.D. et al. : Eosinophilia during gold therapy, Rheumatol. and Rehab., $13:$ 75, 1974. 


\title{
ONE CASE OF INTERSTITIAL PNEUMONITIS DEVELOPED DURING GOLD THERAPY FOR RHEUMATOID ARTHRITIS
}

\section{OSAMU ABE, HIDEO AOKI, RIEKO YAGI, TATSUO SAITO, HIROSHI TANUMA, TAIDO ARAI, SHIGERU TAGAYA, KAZUTOSHI TSUYUZAKI, SHIGEYO HAYASHI, YOSHITSUGU IIJIMA, AND TADANORI KONDO}

\author{
Department of Internal Medicine \\ Isesaki City Hospital
}

One case of interstitial pneumonitis developed during gold therapy for rheumatoid arthritis was reported.

A 44year-old female with rheumatoid arthritis developed dry cough and exertional dyspnea after receiving injection of $445 \mathrm{mg}$ gold sodium thiomalate in total dose. Chest roentgenogram showed diffuse reticular and nodular shadow in the both middle and upper lung fields giving a partial ground glass appearance. Pulmonary function tests revealed restrictive change and impairment of diffusing capacity. As respiratory symptoms appeared in a period of remission of symptoms of rheumatoid arthritis with gold therapy and accompanied by development of stomatitis, skin rash and alopetia with eosinophilia, which commonly occur in gold therapy as side effect. Abnormal shadows in the chest $\mathrm{x}^{-}$ ray film was dominant in the both middle and upper lung fields, the interstitial pneumonitis was diagnosed to be caused by gold therapy.

After administration of corticosteroids (Prednisolone), her subjective symptoms, respiratory functions and chest roentgenograms improved except for remaining of mild reduction of diffusing capacity (after 9 months of follow up).

Comparison of reported 14 cases of gold pneumonitis including this case from 1971 Japan was also disscussed.

Key words Interstitial pneumonitis, Gold therapy, Rheumatoid arthritis. 